\title{
IMPLEMENTATION OF SCIENCE AND TECHNOLOGY IN FEED PRODUCTION TOWARDS SELF-SUPPORTING CATFISH LIVESTOCK
}

\author{
Mastauli Siregar ${ }^{1}$, Elita Dewi ${ }^{2}$ \\ ${ }^{1}$ Lecturer at Prodi Ilmu Kesejahterann Sosial FISIP USU \\ Email : mastaregar07@yahoo.com \\ ${ }^{2}$ Lecturer at Prodi Ilmu Administrasi Negara FISIP USU \\ Email : elitadewi0407@gmail.com
}

\begin{abstract}
Feed is the main key to success in small and large scale catfish farming. If we keep catfish in a large scale, we must be smart to make feed management, of course. It is undeniable that many catfish farmers failed and went bankrupt because they did not know the correct technicalities in catfish farming. Where production costs in catfish cultivation are almost $70 \%$ in feed management.

One alternative that can be done to reduce production costs is to make homemade feed through simple techniques by utilizing local sources of raw materials (including the utilization of agricultural industrial waste) which is relatively cheap. In addition to meeting their own needs, the artificial feed produced can also be sold to markets / other fish farmers so that it can provide multiple benefits. It is not an easy matter indeed to make fish feed itself, it requires special skills to be able to practice it themselves. Farmers must understand what content must be contained in the fish feed.

In connection with this, it is deemed necessary to provide training in making their own catfish feed through simple techniques. It is also necessary to provide guidance and training that enables partners to calculate total sales revenue and total costs so that they are able to find out how much profit is earned per month.

It is expected that after mentoring, partners will become more knowledgeable and able to apply it in their daily work. Thus partners will be more developed, become more economically independent, increase income, become more productive and become more optimistic in their efforts so that the entrepreneurial spirit is built.
\end{abstract}

Keywords : Catfish Livestock Business, Fish Feed, Income Increase

\section{INTRODUCTION}

The business of catfish cultivation is very profitable. Fish that are kept are faster than other freshwater fish. In just three months, catfish can be marketed. The market is never quiet and the price is stable around 8 thousand to 10 thousand rupiah per kilogram. The most desirable catfish are those with 8 tails for one kilogram.
Even though the benefits generated from the catfish farming business are so large, there are various common problems that are faced so that the business they run does not develop. The general problems such as the business capital that is owned is relatively minimal, the number of workers is small, the land is narrow and the marketing method is not right.

When cultivating fish, of course farmers want and crave fish to grow big and 
fat. The most decisive thing in fattening is fish feed. Availability of sufficient quantities of feed. Timely and good nutritional value is one of the most important factors in fish farming business activities. Provision of feed that is not in accordance with the amount of fish that is kept causes the fish growth rate to be slow As a result the production produced is not as expected.

Basically, food sources for maintenance fish come from natural food and artificial feed. Because the amount of natural food in ponds / waters is very limited and inadequate (especially for intensive and semiintensive aquaculture activities), in order to achieve a good fish growth rate it is necessary to provide additional feed or artificial feed according to the needs of fish. If the rate of growth of fish is good, the maintenance time will be shorter so that the productivity of ponds / waters also increases because the period of fish production that is maintained becomes shorter.

Feed is the main key to success in small and large scale catfish farming. If we keep catfish in a large scale, we must be smart to make feed management, of course. It is undeniable that many catfish farmers failed and went bankrupt because they did not know the correct technicalities in catfish farming. Where production costs in catfish cultivation are almost $70 \%$ optimized in feed management. Many people want to get results from catfish cultivation but carelessly manage and optimize the feed itself. Feeding as you wish hoping that the catfish will quickly get bigger, that's very wrong. Not the profits we will get but the losses. Moreover, we use factory feed that is very expensive.

The high cost of buying feed also forces fish farmers to rotate their brains seven times to overcome them. One alternative that can be done to reduce production costs is to make homemade feed through simple techniques by utilizing local sources of raw materials (including the utilization of agricultural industrial waste) which is relatively cheap. In addition to meeting their own needs, the artificial feed produced can also be sold to markets / other fish farmers so that it can provide multiple benefits. It is not an easy matter indeed to make fish feed itself, it requires special skills to be able to practice it themselves. Farmers must understand what content must be contained in the fish feed.

\section{Problems}

a. The low level of knowledge and insights of partners in seeing opportunities to utilize the surrounding natural resources in making their own fish feed.

b. The low skill of partners in making their own catfish feed.

c. The lack of partner business capital to be able to run a catfish business in an effort to increase revenue.

d. The low knowledge of partners in carrying out catfish business effectively and efficiently through profit calculation and good cost analysis, so as to be able to increase revenue significantly.

\section{Solutions}

1. Discussion, convincing partners that catfish farming can be used as a source of income if it is carried out in accordance with an effective and efficient production process.

2. Conduct training by inviting experts who have experience in making catfish feed themselves.

3. Guiding partners to be able to run a catfish business well according to the recommended method.

4. Guiding partners to be able to work on profit calculations and better cost analysis, so they can increase their income.

\section{Output target}

1. Increased partner capacity so that they are able to understand catfish farming effectively and efficiently.

2. Increased partner skills so that they can make their own catfish feed.

3. Increasing the knowledge and insight of partners in looking at marketing opportunities so they can get high selling prices. 
4. Increase the ability and skill of partners in calculating total income and knowing the factors that determine the amount of income. Able to calculate total costs and know how to minimize production costs and enable partners to calculate profits per month.

\section{IMPLEMENTATTION METHOD}

\section{Activity plan}

1. Discussion

Conducted by a service team about planned activities. Based on this discussion, the dedication team will be able to find out the people's interest in the service activities. In addition, it can build high motivation to improve business skills.

\section{Training}

The training is conducted by inviting experts who are already experienced in carrying out making their own catfish feed. It is estimated that there will be 1-2 people who will become trainers in making this feed. In this training, the service team will facilitate and provide all the materials and equipment needed in the business of making fish feed. This training is expected to improve the skills of the partners so that it is almost the same as the skills of the tutors.

3. Guidance

In this training the dedication team will teach how to market harvested produce. In addition, it also provides training to have an entrepreneurial mentality and is able and confident in developing catfish livestock business.

4. Evaluation

Evaluation will be carried out during the implementation of service activities which include observing skills in carrying out catfish business and observing marketing strategies. In addition, an evaluation will be carried out even though the training activities have been completed, namely by asking questions about the progress of the catfish business so far and also by revisiting livestock entrepreneurs asking about the advantages and obstacles encountered after the training activities have been completed.

\section{Contribution of Partner}

1. Partners are willing to take part in all forms of training and intend to change their work methods to be more efficient and effective. Partners will be asked to be active and committed to being able to make catfish feed themselves with simple techniques as recommended.

2. Partners are willing to take part in strategy training in marketing that will be practiced by partners to ensure the success of their business.

Partners are willing to apply what they have been taught to training and are willing to be evaluated.

3. Partners are also willing to take part in training in calculating total income, knowing the factors that determine the amount of sales revenue.

Partners are able to calculate total costs and know how to minimize production costs and are able to calculate profits per month.

\section{Implementation of Activities}

Catfish feed production activities start from the preparation of the program which includes surveying the location of catfish ponds. The survey results show that the obstacles faced by partners in Situmeang Habinsaran include:

1. The high price of catfish feed

2. Simple equipment

3. Erratic weather

4. Lack of supply of superior seeds

5. Lack of capital

Based on these general constraints, it was chosen namely the fulfillment of feed and equipment. The alternative used is making feed from local products. The results of the training were that the partner groups were very enthusiastic and interested in joining the program. This program is considered very relevant amidst the high price of factory-made catfish feed. Motivation to make alternative 
catfish feed has actually been around for a long time, but because there is no equipment support, this effort has not yet proceeded and catfish farmers still use factory-made feed.

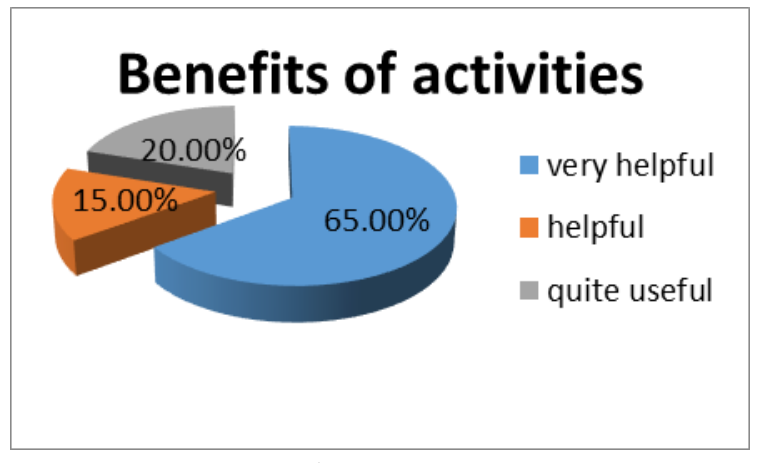

Diagram 1.

This activity felt very useful $65 \%$, useful $20 \%$, and quite useful $15 \%$.

Diagram 2 shows that the submission of content is considered very good $60 \%$, good $35 \%$, and quite good $5 \%$.

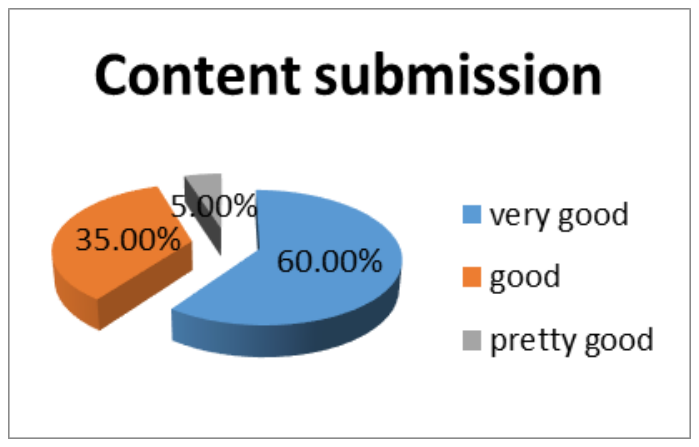

Diagram 2.

\section{RESULT AND DISCUSSIONS}

The biggest cost in the business of enlarging catfish is the cost of feed. About $70 \%$ of the total costs incurred are to buy feed. This is understandable because catfish are very active fish that require large amounts of food. And these catfish eat everything, in the sense that they don't choose the type of food they will eat.

To respond to this, the service team provided counseling to partners specifically in processing catfish feed. The team provides assistance to feed processing machines, so farmers can make their own feed for their pet fish consumption. If the farmer is able to make his own fish food, it is believed that he will provide greater profit margins to the farmers themselves.

Extension activities are agreed to be carried out at partner locations. The counseling method is conducted by the lecture method for all members of the partner group conducted in groups. Furthermore, assistance is provided in the form of equipment and supporting materials for partner businesses.

The service activities continued by providing assistance to service partners regularly and continuously. Partners can actively contact and discuss with the service team using available technology. In addition, to further enhance the interaction between the service team and service partners, the service team also contacted and visited the partner's business premises. A visit to the service partner's place is carried out with the aim that partners can be more effective and efficient in carrying out the production process of their sewing business.

Increased knowledge and skills of partners in processing catfish food is done through counseling and FGD accompanied by bringing in trainers. During the two months a week training to improve these skills continues. Regarding the schedule and place of training submitted to the agreement between partners and invited trainers. This is so that the training can run more effectively and have maximum benefit for partners.

After 2 months of assistance to partners, there was a change in the partners. Partners have been able to make feed for their catfish.

\section{CONCLUSION}

1. Service activities take place well and receive a great welcome from partners.

2. An increase in production and partner productivity. 


\section{ACKNOWLEDGMENTS}

The authors gratefully acknowledge that the present research is supported by University Of North Sumatera and Higher Education Republic of Indonesia. The support is under the research grant Non -PNBP USU of Year $2018 \quad$ Contract Number 172/UN5.2.3.2.1/PPM/2018

\section{BIBLIOGRAPHY}

Alma, Buchari. (2008). Manajemen Pemasaran dan Pemasaran Jasa. Penerbit Alfabeta, Bandung

Brigham, Eugene F and Joel F Houston, 2004, Fundamentals of Financial Management, 10e, International Student Edition, Thomson Learning.

Cravens, David W. (2009). Strategic Marketing. Seventh Edition. Boston: Irwin McGraw-Hill

Ferdinand, Augusty. (2002), Marketing Strategy Making: Proses dan Agenda Penelitian, Journal Sains Pemasaran Indonesia. Vol 1, No.1, Mei, p.1-22
Gunawan, Surya. 2016. Budi Daya Dan Bisnis Lele. Jakarta : Penebar Swadaya.

Hisrich\& Peters, 2002, Entrepreneurship, Fifth Edition.New York:McGraw-Hill Higher Education

Kotler, Phillip, 2008, Marketing Management - The Millenium Edition, Prentice Hall.

Salvatore, Dominick. 2005. Managerial Economics. Edisi Kelima. Jilid Pertama.Jakarta: Salemba Empat.

Suryana, 2006, Kewirausahaan Pedoman Praktis : Kiat dan Proses Menuju Sukses, Jakarta:Salemba Empat

Sutojo, Siswanto, 2003, Manajemen Penjualan yang Efektif, PT. Darma Mulia Pustaka

Van Horne, James and John M. Machowics, JR, 2001, Pinciple of Financial Management, Prentice Hall. 